\title{
Urban Forestry and Ecosystem Services in the City of Dolisie (Congo)
}

\author{
Victor Kimpouni ${ }^{1,2, *}$, Jean De Dieu Nzila ${ }^{1,2, ~ *}$, Hervé Fortuné Kaya ${ }^{1}$ \\ ${ }^{1}$ Higher Teacher Training College (ENS), Marien Ngouabi University, Brazzaville, Congo \\ ${ }^{2}$ National Forestry Research Institute (IRF), Brazzaville, Congo \\ Email address: \\ vkimpouni@yahoo.com (V. Kimpouni),jddnzila@yahoo.fr (J. De D. Nzila) \\ ${ }^{*}$ Corresponding author
}

\section{To cite this article:}

Victor Kimpouni, Jean De Dieu Nzila, Hervé Fortuné Kaya. Urban Forestry and Ecosystem Services in the City of Dolisie (Congo). American Journal of Agriculture and Forestry. Vol. 7, No. 2, 2019, pp. 53-65. doi: 10.11648/j.ajaf.20190702.13

Received: January 14, 2019; Accepted: March 24, 2019; Published: April 29, 2019

\begin{abstract}
The study, conducted in the city of Dolisie, provides an overview of plant diversity, ethnobotanical and ecosystem services, people's expectations and perceptions of urban forestry. It is based on the botanical inventory and interviews involving city managers and populations. A total of 34 species belonging to 26 genera and 17 families have been recorded with a fruit tree dominance. The role and importance of trees in urban areas is well perceived by the population. Gender and education level influence urban forestry preferences and expectations. Men with at least a secondary level of education exploit the aesthetic aspects of the environment, while women and individuals with at most a primary level like food, phytotherapeutic and financial aspects. The 10 urban forestry properties identified constitute three categories whose ethnobotanical use values stand out: supply services with 1.96 and regulation services with 1.97. A gender and educational level analysis reveals differences, sometimes significant, in the ethnobotanical use value of a property. As for the level of fidelity, it is carried by the same taxa, especially fruit trees, both in food and phytotherapy. At a time when humanity is suffering from the harmful effects of climate change, the value of urban forestry is undeniable in mitigating the heat islands generated by our cities.
\end{abstract}

Keywords: Congo, Urban Forestry, Ethnobotanical Use Value, Plant Diversity, Ecosystem Services, Level of Fidelity

\section{Introduction}

The concept of urban forestry began in the United States in the late 1960s and spread to Canada, Europe and Australia [1]. Urban forestry has been developed mainly for aesthetic reasons and ecological benefits [2]. To this end, urban forestry (care, treatment, forestry) has become a real business. It covers urban arboriculture, green spaces and peri-urban forest. Many private urban forestry companies offer their services to cities, institutions, city dwellers and businesses of all types. Notwithstanding the services, several specialized socioprofessional categories in the sector such as urban forest engineers, urban foresters, arboriculturists, architects, urban planners, appraisers, insurers, and lawyers have emerged [1].

The concept of urban forestry is a recent development in developing countries [1]. To this end, many case studies were conducted by FAO in the period 1995-2009. In Asia, from 1996 to 1997, mention should be made of China (Hong Kong),
Malaysia (Kuala Lumpur), Singapore (Singapore) and Iran (Tehran)]; in Latin America, from 1995 to 1996, Brazil (Rio de Janeiro) and Ecuador (Quito)]; in Africa, mention Egypt (Cairo), Senegal (Dakar), Niger (Niamey), Mauritania (Nouakchott), Burkina Faso (Ouagadougou), and Chad (Ndjamena) [1, 3]. In addition to these cases, the theme of urban and peri-urban forestry has been of interest to many researchers in developing countries [4-5] in Togo; [6] in the DRC; [7-13] in Congo.

In Africa, particularly in sub-Saharan Africa, cities face problems of degradation and regression of urban forest areas, urban green space development and management [14]. This is the case of the Patte d'Oie reserve in Brazzaville and the Eucalyptus forest massif in Pointe-Noire. Indeed, despite being set aside in 1938, the original area of the Patte d'Oie forest has decreased from 240 to 95 ha, with less than 10 ha of natural forests [8-9]. The spatial and demographic growth of cities is a remarkable fact of the contemporary era [15]. The combination of these two factors in developing countries, such as Congo, 
where the urbanization rate is about $69 \%$, aggravates the anthropogenic effects on urban and peri-urban forests [16]. In order to mitigate biodiversity loss, urban forestry is an ideal alternative through the many benefits offered directly and indirectly to the city and its people [17-19]. These functions include: ecological; aesthetic; aesthetic; phytotherapeutic; social and recreational; educational; and economic.
The objective of this study is to contribute to a better knowledge of urban forestry in the city of Dolisie, through: the tree floristic composition; the perception and expectations of populations (direct and indirect ecosystem services); the negative impact of urban trees on roads and other physical infrastructure.

\section{Materials and Methods}

\subsection{Presentation of the Study Environment}

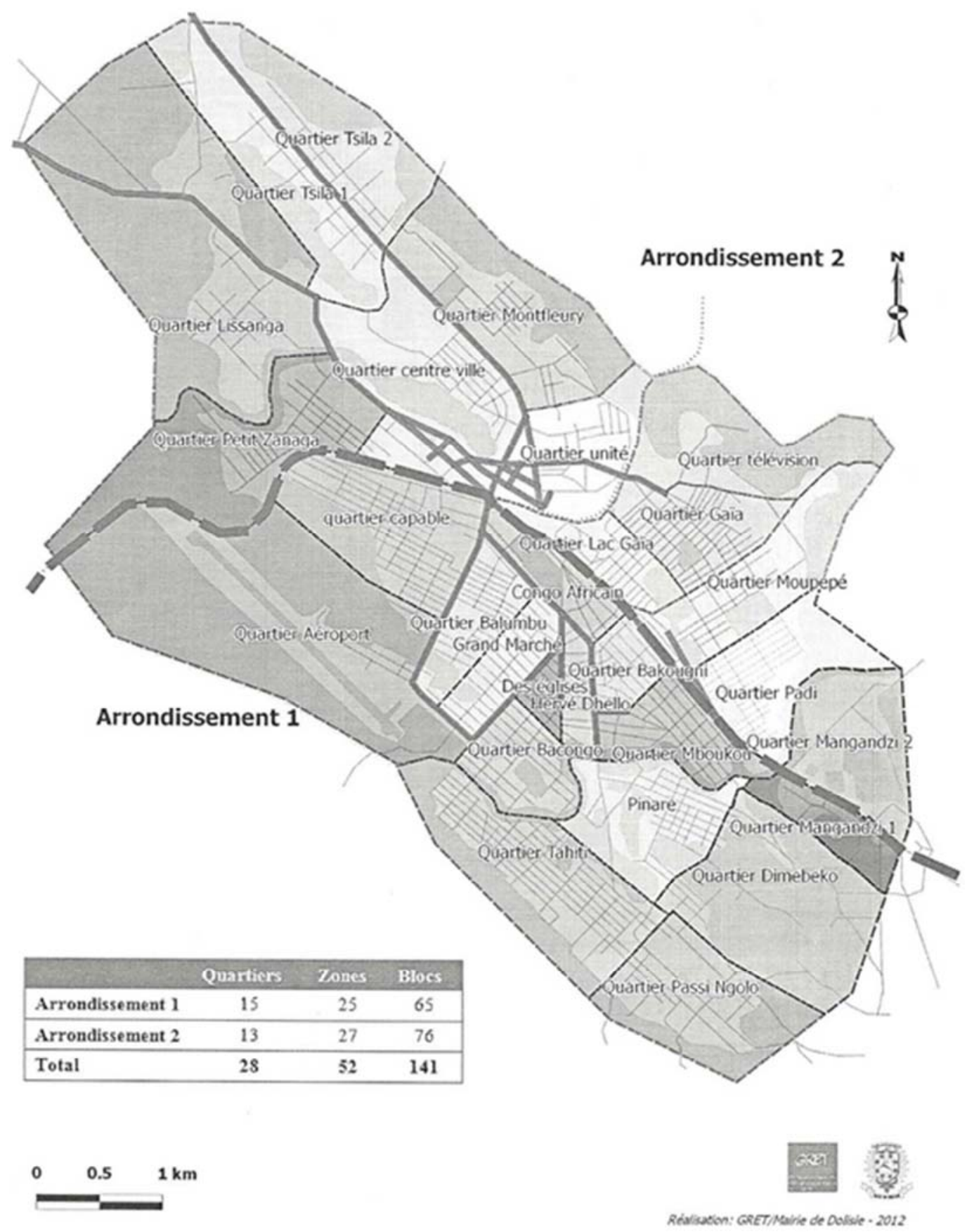

Figure 1. Urban area of Dolisie (source: GRET/Mairie de Dolisie, 2012).

The Republic of Congo, straddling the equator, is located in Central Africa. It extends from southwest $\left(11^{\circ} 11^{\prime} \mathrm{E} ; 5^{\circ} 00^{\prime}\right.$
S) to northeast $\left(18^{\circ} 35^{\prime} \mathrm{E} ; 3^{\circ} 34^{\prime} \mathrm{S}\right)$ and covers an area of $342,000 \mathrm{~km}^{2}$ for a population of $3,697,492$ inhabitants, or a 
density of 10.8 inhabitants per $\mathrm{km}^{2}$ [20]. This study was conducted in Dolisie, the $3^{\text {rd }}$ largest city in the Congo, located in the middle of the Pointe-Noire - Brazzaville axis. Created by Albert Dolisie in 1934 (a former companion of explorer Pierre Savorgnan DE BRAZZA) following their exploration mission that led to the Congo becoming a French Colony, the city of Dolisie (named after its creator) is located in the southern part of the Congo more than $350 \mathrm{~km}$ from Brazzaville, the country's political capital. It is the capital of the Niari Department. The city extends between $12^{\circ} 40^{\prime}$ East longitude and $4^{\circ} 12^{\prime}$ South latitude (Figure 1). It covers 18.3 $\mathrm{km}^{2}$ for 83,798 inhabitants, or 4,579 inhabitants per $\mathrm{km}^{2}$ [20].

The climate is of the equatorial type of transition called low-Congolese [21-23]. It is characterized by: an average annual temperature oscillating around $25^{\circ} \mathrm{C}$, with an average annual temperature amplitude of $4^{\circ} \mathrm{C}$; annual precipitation of around 900 to $1400 \mathrm{~mm}$, the basis for the alternation of 2 seasons. The dry season is well marked from June to September and the rainy season from October to May, with a slowdown in rainfall in January and February. The most watered months are November, March and April (Figure 2). Relative humidity is particularly high and always above $70 \%$ on an annual average (Figure 2).
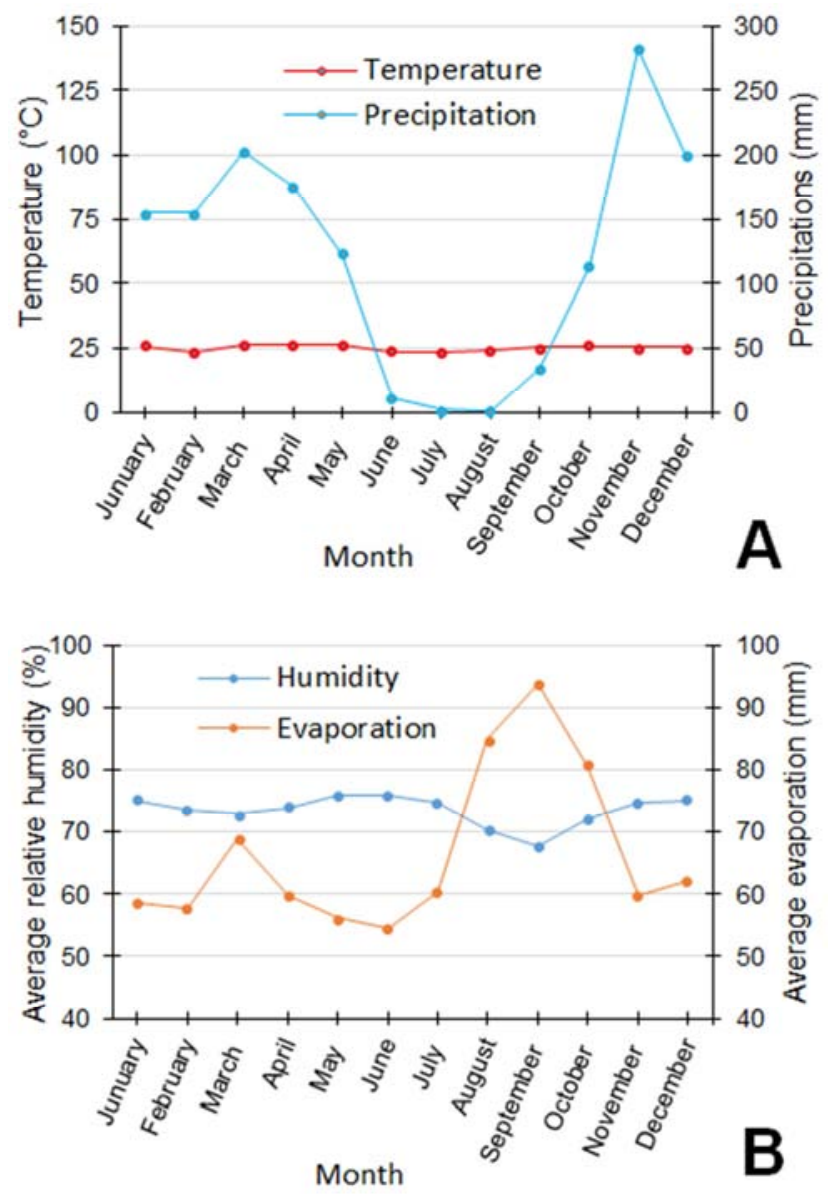

Figure 2. Synoptic of the climate parameters (source ANAC 2017).

Legend: ombrothermic curve (A); variation of relative humidity and evaporation (B)
The city of Dolisie is built on part of the plain surrounded by the Mayombe forest massif, the hills that border the alluvial plains of the Niari Valley. The topography of life is thus made up of a succession of high flat lands and valleys at the bottom of which ponds develop, which are in fact dolines resulting from the karst landscape of the Schisto-calcareous geological series.

The soils are ferrallitic, highly desaturated, yellow reworked and acidic, with a $\mathrm{pH}$ ranging from 4 to 5 . Developed on clayey material derived from schistolimestone, these soils are of fairly good or good agronomic value; they are deep, well-structured but chemically poor with satisfactory organic matter and nitrogen contents on the surface [24].

The city of Dolisie is watered by the Loubomo River and its two tributaries, the Pinaret and the Mikokoto.

\subsection{Study Materials}

The plant material consists mainly of trees and shrubs in the urban ecosystem. Specimen identification was done in situ for common and/or ex situ taxa at the national herbarium (IEC) by comparing the herbarium and the diagnoses of the Central African Flores, Gabon and Cameroon. The ordination and nomenclature correspond respectively to APG IV [25] and [26].

\subsection{Study Methods}

\subsubsection{Socio-economic Survey}

The collection of socio-economic data was carried out through individualized interviews or focus groups carried out from 1 to 20 April 2017. The panel of informants consists of 460 people, 250 of whom are women. The selection criterion is the level of education (Table 1).

Table 1. Data on the survey population.

\begin{tabular}{|c|c|c|c|c|}
\hline \multirow{2}{*}{ Education level } & \multirow{2}{*}{$\begin{array}{l}\text { Men } \\
\text { number }\end{array}$} & \multirow{2}{*}{$\begin{array}{l}\text { Women } \\
\text { number }\end{array}$} & \multicolumn{2}{|c|}{ Total of informants } \\
\hline & & & Number & $\%$ \\
\hline No level & 45 & 52 & 97 & 21,4 \\
\hline Primary & 56 & 64 & 120 & 26,0 \\
\hline Secondary & 61 & 87 & 148 & 31,6 \\
\hline Higher & 48 & 47 & 95 & 21,0 \\
\hline Total & 210 & 250 & 460 & 100,0 \\
\hline
\end{tabular}

\subsubsection{Specialized Interviews}

Personalized interviews with the managers and technicians of the Dolisie Town Hall made it possible to characterize the management of urban trees and to assess the harmful impact of these trees on the local infrastructure.

\subsubsection{Floral Inventory}

The inventory of the tree flora was carried out as follows: (i) a travelling survey; (ii) and a plot inventory of $9,600 \mathrm{~m}^{2}$ $(120 \mathrm{~m} \mathrm{x} 80 \mathrm{~m})$ areas, i.e. 0.9 ha. Each plot corresponds to 24 residential plots of $400 \mathrm{~m}^{2}(20 \mathrm{~m} \mathrm{x} 20 \mathrm{~m})$. A total of 200 plots, or $8,000 \mathrm{~m}^{2}$, were inventoried. The first type of inventory was carried out throughout the city and the second in the districts of zones A and B. It is noted the dbh of each individual, according to Dallmeier [27]. 


\subsection{Data Processing}

Data on ecosystem services have been classified into three categories according to Millennium Ecosystem Assessment [28-29]: supply services that provide appropriate goods through ecosystem use; regulatory services; and cultural services. The data were analyzed on the basis of ethnobotanical indicators. The ethnobotanical use value (VU) was calculated for each of the three categories of ecosystem services. The total use value (VUt) of the species was determined from the adapted formulas of [30] and [31]:

$$
V U=\frac{\sum_{i}^{n} U i}{\mathrm{n}} \text { soit } \mathrm{VUt}=\sum_{1}^{p} \mathrm{VU}
$$

With $\mathrm{Ui}=$ number of citations per ecosystem service and $\mathrm{n}$ $=$ total number of people surveyed.

The Informant Consensus Factor (FCI) adapted from [32] and the Level of Fidelity (NF) were used to determine the relative importance of ecosystem services provided by urban arboriculture. The CFI generally supports ethnotherapy to identify species valued by the community, agree on their uses and possibly consider further studies [32-34]. The CFI value ranges from 0 to 1 and indicates a high consensus when it tends towards 1 .

$$
F C I=\frac{N u r-N 1}{N u r-1}
$$

With Nur $=$ number of citations in each category of ecosystem services and $\mathrm{N} 1=$ number of ecosystem services in each category.

The level of fidelity (NF) is calculated within each category of ecosystem services using the adapted formula of [35].

$$
N F=\frac{N p}{N} \times 100
$$

With $\mathrm{Np}=$ number of people citing an ecosystem service or use type and $\mathrm{N}=$ total number of people deriving any ecosystem service from it.

\section{Results}

\subsection{Phytodiversity and Taxonomic Data}

Thirty-four species belonging to 26 genera and 17 families were recorded in the study sites, indicating a low diversity of tree flora; 16 additional species were recorded outside the selected sites. The best represented families are the Fabaceae, which account for $26 \%$ of the species, Moraceae (12\%), Anacardiaceae, Arecaceae and Combretaceae are respectively at $9 \%$, and, to a lesser extent, Myrtaceae and Rutaceae with $5.88 \%$. The fruit trees constituting $23.5 \%$ of the survey are based on 9 species.

\subsection{Typology of Urban Arboriculture}

\subsubsection{Alignment Shafts}

The alignment trees are present in the city centre and partly on Avenue de la République, which links the city centre to Ngot-Nzoungou airport. A total of 353 alignment trees have been identified; the most represented taxa are: Mangifera indica, Milletia laurentii, Terminalia mantaly and taxa of the genus Eucalyptus (Figure 3).

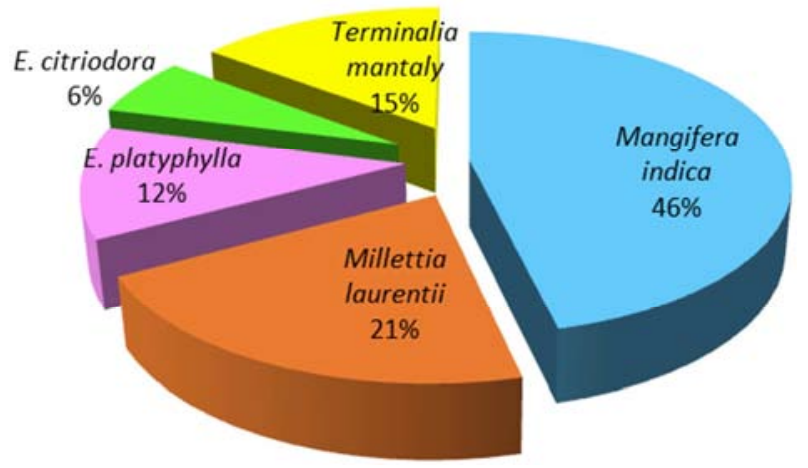

Figure 3. Contribution of taxa from alignment trees in the city of Dolisie.

\subsubsection{Yard Trees}

Courtyard trees abound and generally dominate in the plots. Many are elderly and some have senescence cavities. They shade and decorate concessions while providing edible products (fruits, leaves) and medicinal products to populations. These different interests of trees are variously appreciated by the populations. This explains the variability in the choice and heterogeneity of tree types, from one plot to another and even from one neighbourhood to another. The most common trees are Persea americana, Mangifera indica, Carica papaya, Dacryodes edulis, Spondias cytherea and Annona muricata.

\subsubsection{Public Garden Trees}

The only public garden is located at the intersection of Jean Jacques Mouaya Avenue and Michel Moutsassi Street. The botanical inventory of the tree flora of the said public garden gives four species, three genera, three families and ten individuals.

\subsubsection{Trees of Intra-urban Plantations}

The city of Dolisie has some rare small intra-urban forests, including the artificial forest composed mainly of Eucalyptus citriodora and Eucalyptus platyphylla. Less than one hectare in size, it is located in front of the presidential palace, opposite the Dolisie General Hospital.

\subsubsection{Concession Delimitation Trees}

Essentially made up of small diameter trees and shrubs, they form living hedges that delimit private concessions. This practice, which would be described as ecological, compensates for the low elevation of party walls made of durable materials, due to the lack of finance or a related culture. The species commonly used are Millettia versicolor, Spondias mombin and Mangifera indica in the popular districts and Eucalyptus citriodora, Eucalyptus platyphylla and Pinus caribaea in the residential districts.

\subsubsection{Ecosystem Values of Urban Forestry}

The ten ecosystem services that flow from inventoried 
properties fall into three major categories (Table 2). Between genders, ecosystem use values are not very different. In both cases, they range from 0.10 to 0.95 . The total ecosystem use value ranges from 0.16 to 1.97 . Supply and regulation services are the ones to which people attach the most interest, compared to cultural services whose value is greatly underestimated or even ignored at the current stage of urban development.

Table 2. Ecosystem services and ethnobotanical use value.

\begin{tabular}{|c|c|c|c|c|c|}
\hline Services & Men Citations & Women citations & Men VU & Women VU & VUt \\
\hline Procurement services & - & - & - & - & 1,96 \\
\hline Fruits & 199 & 232 & 0,95 & 0,93 & 0,94 \\
\hline Woody energy & 13 & 65 & 0,06 & 0,26 & 0,17 \\
\hline Income generation & 73 & 102 & 0,35 & 0,41 & 0,38 \\
\hline Regulatory services & - & - & - & - & 1,97 \\
\hline Shading & 180 & 162 & 0,86 & 0,65 & 0,74 \\
\hline Erosion control & 20 & 25 & 0,10 & 0,10 & 0,10 \\
\hline Climate change & 63 & 52 & 0,30 & 0,21 & 0,25 \\
\hline Pollutant remover & 118 & 130 & 0,56 & 0,52 & 0,54 \\
\hline Cultural services & - & - & - & - & 0,16 \\
\hline Aesthetic & 42 & 30 & 0,20 & 0,12 & 0,16 \\
\hline
\end{tabular}

Legend: Ethnobotanical use value (VU), total ethnobotanical use value (VUt)

\subsubsection{Informing Consensus Factors for Ecosystem Services (CFI)}

The informant consensus factor for ecosystem services is calculated for food, herbal medicine and income sources. In terms of food, the CIF is 0.91 , while between genders, there are 0.94 for men and 0.95 for women respectively. At the phytotherapeutic level, it is 0.93 compared to 0.83 for men and 0.87 for women. As for sources of income, the CFI for men and women is 0.72 and 0.80 respectively, while it is 0.89 overall. These data perfectly illustrate the convergence of views that the populations of the region have on the different categories.

\subsubsection{Level of Fidelity of Ecosystem Services}

The level of fidelity of food taxa is between 0.46 and $34.33 \%$. The most notable species are those consumed on a daily basis and also the most representative within urban arboriculture (Table 3). In terms of phytotherapy, the level of fidelity varies from 0.93 to $31.02 \%$. Once again, it is the same taxa that are in sight, except Dacryodes edulis.

Table 3. Level of fidelity of food and medicinal taxa.

\begin{tabular}{|c|c|c|}
\hline \multirow{2}{*}{ Taxa } & \multicolumn{2}{|l|}{ Fidelity level } \\
\hline & Alimentation & Therapeutic \\
\hline Annona muricata $\mathrm{L}$ & 1,15 & 6,02 \\
\hline Carica papaya $\mathrm{L}$. & 0,46 & 5,56 \\
\hline Ceiba pentandra Gaertn. & - & 0,93 \\
\hline Citrus sp. & 0,69 & 6,02 \\
\hline Cocos nucifera $\mathrm{L}$ & 0,46 & - \\
\hline Dacryodes edulis (G. Don) H.J. Lam. & 11,29 & 5,56 \\
\hline Ficus vogeliana Miq. & - & 3,24 \\
\hline Mangifera indica $\mathrm{L}$. & 34,33 & 31,02 \\
\hline Millettia laurentii De Wild. & - & 0,93 \\
\hline Millettia versicolor Welw. ex Bak. & - & 0,93 \\
\hline Persea americana Mill. & 23,27 & 13,43 \\
\hline Senna siamea (Lam.) H.S.Irwin \& Barneby & - & 2,78 \\
\hline Spondias cytherea Sonn. & 7,14 & - \\
\hline Trilepisium madagascariense DC & 0,46 & 5,09 \\
\hline
\end{tabular}

\subsection{People's Perceptions and Expectations of Urban Forestry}

The perceptions and expectations of Dolisie's populations regarding urban forestry, depending on the level of study, are many and varied (Figure 4). Apart from the exploitation associated with traditional herbal medicine, the source of income and fuel wood where women excel, men are more aware of the environmental issues associated with urban arboriculture. The contribution of men to the various ecosystem services ranges from 11 to $95 \%$, compared to 8 to $92 \%$ for women. Depending on the gender, preference is given to food, shade and clean-up with $50 \%$ of citations. Depending on the level of education, the gender difference is very small. Rates range from 92 to $98 \%$ for men and 89 to $96 \%$ for women. 


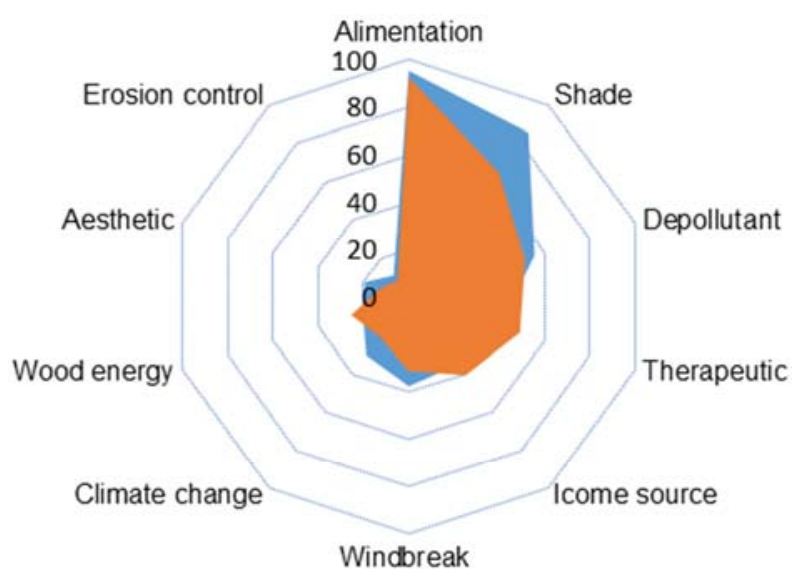

= Men $=$ Women

Figure 4. Needs and expectations of populations.

\subsubsection{Procurement Services}

i Food requirement

Food is the most important need of urban forestry respondents. It interests $95 \%$ of men and $93 \%$ of women. The most popular fruits are Mangifera indica, Dacryodes edulis, Persea americana and Spondias cytherea. This nutritional interest changes inversely with education level. For men, rates range from 92 to $98 \%$, while they range from 89 to $96 \%$ (Figure 5A).

ii Pharmacological interest

$45 \%$ of men and $49.20 \%$ of women say they are interested in urban trees for their medicinal properties (Figure 5B). The organs (roots, leaves, bark) of some urban trees are used in traditional pharmacopoeia. The exploitation of this virtue evolves in the opposite direction to the level of education. Let us note the rates from 21 to $67 \%$ for men and from 25.53 to $73.07 \%$ for women. The majority of traditional therapists and their patients are farmers.

iii Creation of a source of income

More than $35 \%$ of men and nearly $41 \%$ of women say they are interested in urban trees for the sale of their edible fruit (Figure 5C). The need decreases as education levels rise and women are the most involved in this activity. The survey shows a rate of 12.5 to $58 \%$ for men and 21 to $63.46 \%$ for women. The most popular fruits are Mangifera indica, Dacryodes edulis, Persea americana and Spondias cytherea.

iv Wood-energy requirement

$6 \%$ of men and $26 \%$ of women, respondents, are interested in urban trees for fuelwood (Figure 5D). The need for wood energy decreases as the level of education increases. Women (10.63 to $42.30 \%)$ are more concerned by this activity than men $(4.16$ to $37.77 \%)$. The most felled urban trees are Mangifera indica for firewood, used in charcoal production and brick firing. This activity, carried out by young men during the dry season, is very regular in the outlying districts of the city. These young people prefer to buy and fell urban trees close to their activities to minimize transportation costs.

\subsubsection{Regulatory Services}

i Need for shade

Shading is the second need expressed by $85.71 \%$ of men and $64.8 \%$ of women (Figure 5E). Regardless of the level of education, differences are less pronounced among men (87 to $85 \%)$. On the other hand, the need for shade decreases with increasing educational attainment and among women (71 to $57 \%)$.

\section{ii Role of depolluter}

Nearly $56 \%$ of men and $51.66 \%$ of women say they are interested in urban trees for their air pollution control effects (Figure 5F). The interest of this parameter changes with education: 31.11 to $83.33 \%$ of men; and 29 to $72.34 \%$ of women. This data shows that it is after the primary cycle that awareness of the contribution of trees to air pollution control is more important.

iii Windbreak function

Nearly $38 \%$ of men and $31 \%$ of women use the windbreak function of urban trees (Figure 5G). The survey shows that interest decreases with education level, Figure 5G shows that men are generally the most interested. Indeed, the rate for men varies from 28.73 to $42.62 \%$, compared to 23.40 and $42.30 \%$ for women.

iv Fight against global warming

More than $30 \%$ of men and nearly $21 \%$ of women recognize urban trees as a contribution to the fight against global warming (Figure 5H). Figure 12 shows that the need to combat global warming increases with education level. Men are the most interested (11.11 to 50\%) ahead of women (7.69 to $38.29 \%$ ). These results reflect that awareness of climate change is higher. Similarly, most respondents in the uneducated and primary categories claim to be aware of this global scourge through the media (television, radio) and schools.

v Erosion control

The fight against erosion is the least important need for urban forestry in the City of Dolisie. Indeed, $11.95 \%$ of men and $8 \%$ of women say they are interested in urban trees to fight against erosion (Figure 5I). The proportions in terms of contribution are 6.38 to $14.28 \%$ of men and 6.25 to $9.61 \%$ of women. These low percentages could be justified by the clayey nature of the city's soils, which are less vulnerable to water erosion.

\subsubsection{Cultural Services}

Aesthetic function: ornamental is one of the least important needs of urban forestry respondents $(19.52 \%$ male and $12 \%$ female). The need for ornament increases as the level of education increases. Men are involved from 4.44 to $31.14 \%$, while women's rate is between 3.84 to $17.02 \%$ (Figure 5J). It should be noted that the rate of this property varies concomitantly with the level of education and income of the inhabitants, particularly in the "wealthy neighbourhoods". 

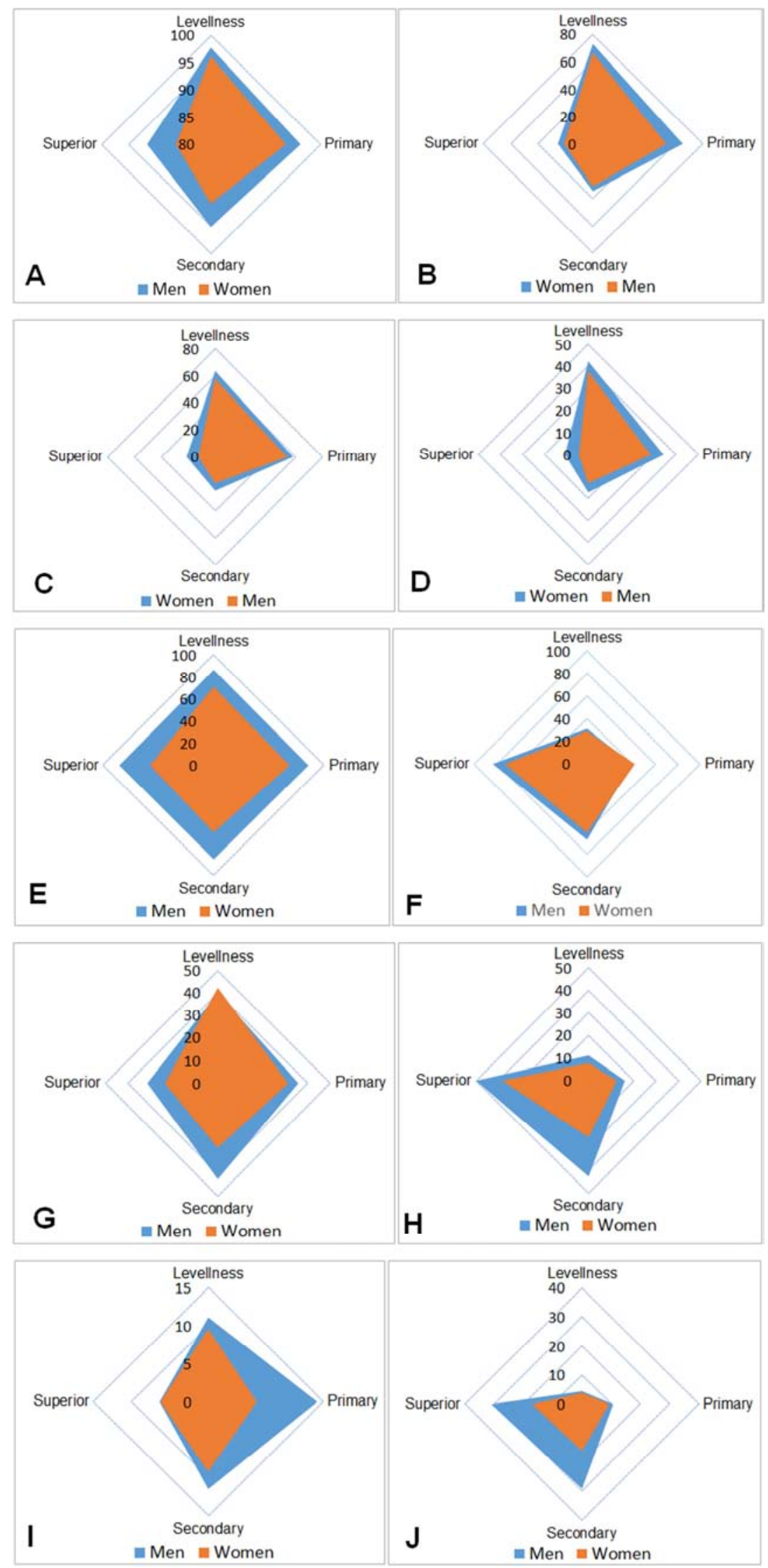

Figure 5. Ecosystem goods and services in urban forestry by gender and level of study.

Legend: Food needs (A), phytotherapy (B), source of income (C), wood energy (D), Shade needs (E), pollution control (F), wind screen (G), Climate change $(\mathrm{H})$, erosion control (I), esthetic $(\mathrm{J})$. 


\section{Discussion}

\subsection{Floral Analysis and Sustainable Management}

The floral procession is essentially centred on non-native species. The floristic distribution and densification in the city area seems to reflect the social level of the populations. The species Mangifera indica, Millettia laurentii, Eucalyptus sp. and Terminalia mantaly characterize the alignment trees. The first being, as in Brazzaville, the only fruit species used in alignment since colonial times $[7,13]$. These trees, most of which are senescent, lack maintenance to the point of constituting a danger to users. In addition to this aspect, the damage caused to urban roads is a financial concern for city managers.

Courtyard trees are numerous in the city and fruit trees (Mangifera indica, Dacryodes edulis, Persea americana, Carica papa, Spondias cytherea, Annona muricata) are more popular in the working-class districts, where incomes are lowest [13]. In addition to the financial aspect, the phytotherapy aspect is one of the factors determining the floristic choice. However, a distinction needs to be made between the outlying districts (Dimébeko and Tsila) where there is at least one fruit tree in $3 / 4$ of plots, and the old districts, such as Bacongo and Baloumbou, where fruit trees are being replaced by commercial buildings. This phenomenon of uncontrolled tree felling, in compliance with current regulations, simultaneously leads to a reemission of carbon sequestered in the atmosphere and accentuates the manifestation of the city's heat island. Indeed, they provide wood energy that is generally used to bake bricks. In the city centre, however, ornamental species (Pinus caribaea, Tectona grandis, Elaeis guineensis) are preferred to fruit trees [13]. Indeed, in this sector of the city where public administration, commerce and services are concentrated, aesthetics is an element of conviviality.

The city's only public "garden" is poor in specific and floristic richness. This double weakness is nothing other than a tangible illustration of the non-fulfilment of the functions assigned to green spaces, whatever their status [36]. Indeed, trees are the basis for the development of green spaces and their functionality [37-38]. Notwithstanding the low tree cover, this green space is very poorly managed. As the municipality has legally transferred the management of its assets to a third party, access and/or attendance is subject to consumption (purchase of a drink and/or a meal). As described, this green space is no more than a private open-air restaurant/bar. As such, it cannot be considered a public green space. Spoliated by the manager, the ornamental species (Delonix regia, Eucalyptus citriodora, Eucalyptus platyphylla, Terminalia mantaly, Pinus caribaea) are the plant markers.

The arborisation of the city dates back to the colonial period when the surface area of the city was very modest and the management of trees more rational, recognize many active and retired managers of the town hall. The trees were permanently planted and maintained by the colonial administration. It regularly replaced damaged and/or senescent trees. This operation was aimed at beautification, shading, wind protection and dust collection in the downtown area. From independence to the present day, the city and the city centre have expanded considerably. The management of the city's trees and green spaces has seen varying fortunes. The management of urban forestry in Dolisie faces multiple problems, including: uncontrolled growth in the urban area; the absence of a real municipal urban arboriculture policy; the lack of enforcement of regulations on sustainable tree management in urban areas; and low public awareness of the role and function of trees in urban areas. The planting of a few clear-sighted individuals of Terminalia mantaly along Avenue de la République is an illustration of the value of the credit allocated to this component.

\subsection{Analysis of the Value of Ethnobotanical Use}

The values of the ethnobotanical data illustrate that populations, on the whole, have a strong knowledge of the benefits of trees. The focus is on supply and regulatory service goods. As the city has almost no public green space, the properties associated with the cultural service are almost ignored by the population. The latter reflect the management of the city. This study, which corroborates the findings of [12-13] in Brazzaville, marks fruit trees as the first floristic component. As the majority of the population forms the underprivileged social stratum, the choice of plants is influenced by 3 pillars: food; therapy; and income.

\subsection{Development of Urban Arboriculture}

The role and importance of urban arboriculture in the city is well understood by the population $[6,17]$. Indeed, trees in urban areas contribute to the well-being of populations and the satisfaction of basic needs: food, health, housing, clothing, education and recreation [12, 13, 38]. Similarly, urban trees reduce the heat island effect generated by the city, protect from wind, noise and dust [7, 13, 39]. Create a microclimate generating many informal sector activities, as [15] notes. In addition, urban trees enhance the aesthetic value of arteries and landscapes through the exuberance of foliage and flowers [15].

\subsubsection{Direct Benefits}

Fruits and vegetable leaves provide a source of subsistence and income for more than one family, especially at very low income levels [7, 12, 13, 40]. Mature and ripe fruits are a source of nutrients (vitamins, sugars, trace elements...) for human and animal populations (pollination and dissemination agents). In addition to this category of organs, the use of vegetable leaves (Trilepisium madagascariense) to meet trophic needs is one of the primary expectations of urban forestry $[13,18]$.

Urban arboriculture is a phytotherapeutic well, for populations whose low purchasing power does not allow 
them to afford "quality" care at prohibitive costs. With more than a dozen taxa with proven medicinal properties (Mangifera indica, Spondias mombin, Annona muricata, Ceiba pentandra, Dacryodes edulis, Senna siamea, Terminalia superba, Persea americana, Ficus vogeliana, Elaeis guineensis, Millettia laurentii, Millettia versicolor), urban floriculture is a rampart against disease [3, 38]. Indeed, the many tangible signs of anthropogenic debarking confirm the perception and expectations of populations [11-12]. However, this activity, which is beneficial to human well-being, affects the tree population by disrupting their metabolism and exposing internal organs to pathogenic microorganisms and boring insects [11-12].

The city's building is mainly made of baked bricks, which is a cheap material. Brick baking requires logs as an energy source, felling urban trees is the solution. This reality, which is very detrimental to the environment, has considerably affected their population, particularly Mangifera indica and Eucalyptus sp. The recent installation of a cement plant on the outskirts of the city has not reversed the trend as desired. The reasons are associated with the low standard of living of the populations, finding the cost of the blocks and/or inputs (cement and sand) used to shape them prohibitive.

\subsubsection{Indirect Benefits}

The therapeutic virtues of trees are probably unconsciously exploited in the city's hospitals, as the work of psychologists stipulates. Ulrich [41] reported that patients with a view of vegetation recovered more quickly from surgery with fewer post-operative complications than those with windows overlooking a wall. Urban arboriculture would have a positive influence on hospitalized patients. In addition to this therapeutic aspect, urban green spaces have an important educational interest. They provide a good framework for walking classes thanks to their biodiversity [38]. Indeed, the green spaces provide the animal and plant material necessary for making life-size observations. In addition, urban trees are true reservoirs of biodiversity [11, 38]. Indeed, a multitude of living, microscopic and macroscopic beings find a habitat of choice there. This is the case for epiphytes and parasites. In addition, green spaces are places for reading, recreation, leisure, recreation and other activities that contribute to the development of the individual [7, 38].

At the ecological level, urban forestry is one of the levers in the fight against climate change, particularly urban heat islands [38]. Indeed, trees contribute to the mitigation of greenhouse gas (GHG) emissions through carbon sequestration $[38,42]$. The dbh is one of the key parameters in the estimation of above-ground and below-ground tree biomass, as shown by the different allometric equations [43].
Since dbh is most often correlated with sequestered carbon, the sequestration capacity is lower as the biomass is optimal. This situation is almost the present case of the urban arboriculture of Dolisie, where most of the trees recorded have reached the maximum $\mathrm{dbh}$ and some have senescence cavities. Although these trees are an important carbon reservoir stored in their tissues, their low consideration in city development plans results in the recharging of the carbon cycle [44]. Two major sources of carbon re-emission into the atmosphere are identified in Dolisie: baking bricks that require large stocks of energy wood; and standing rot in senescent trees.

In relation to the achievement of sustainable development objectives, urban forestry would be a key component. These objectives stipulate:"... that cities and human settlements are inclusive, safe, resilient and sustainable";"... combat climate change and its impacts";"... preserve and restore terrestrial ecosystems, ensuring their sustainable use".

\subsubsection{Analysis of the Costs Induced by Urban Trees}

Urban trees do not only benefit municipalities and populations. Poorly managed, they are a source of pollution and/or nuisance to the urban environment and the destruction of roads and even infrastructure [40]. Within the population, the damage caused by fruit trees on others often poison good neighbourly relations.

Notwithstanding these aspects of cohabitation, the services in charge of the municipality's management are concerned about financial concerns for the rehabilitation of roads and other infrastructure that are victims of the root system and/or tree branches. In addition to obstructing artificial and natural outlets, trees can cause public health problems, including allergies [45-48].

\section{Conclusion}

The importance of urban arboriculture is no longer to be demonstrated since it represents a source of direct and indirect benefits, both at the population and global level. Thus, urban development plans should evolve by placing the tree and its services at the centre of people's well-being. The ratio of square to square per capita illustrates the efforts required to meet sustainable development objectives. Despite the fact that the people of Dolisie are aware of the importance of trees in the city and the various roles they play, awareness of their ecological functions is necessary to reach a wider public. The future of urban forestry in Dolisie depends on massive planting along the arteries, the creation of spaces and the replacement of all senescent trees. The importance of the tree for the city of Dolisie is evident in the management of many ponds, using fast-growing species such as the eucalyptus, which are well adapted to the environment. 


\section{Appendix}
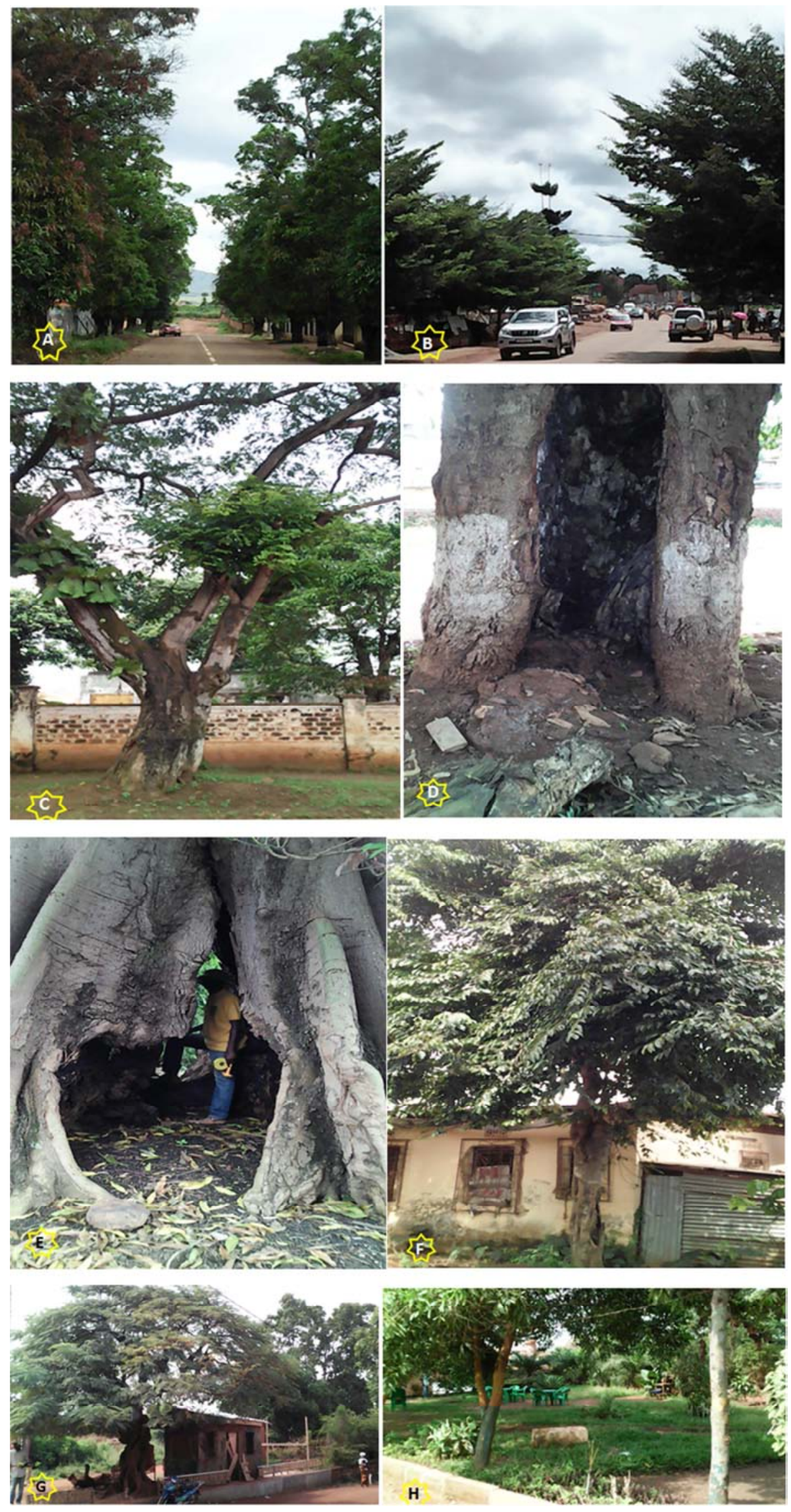

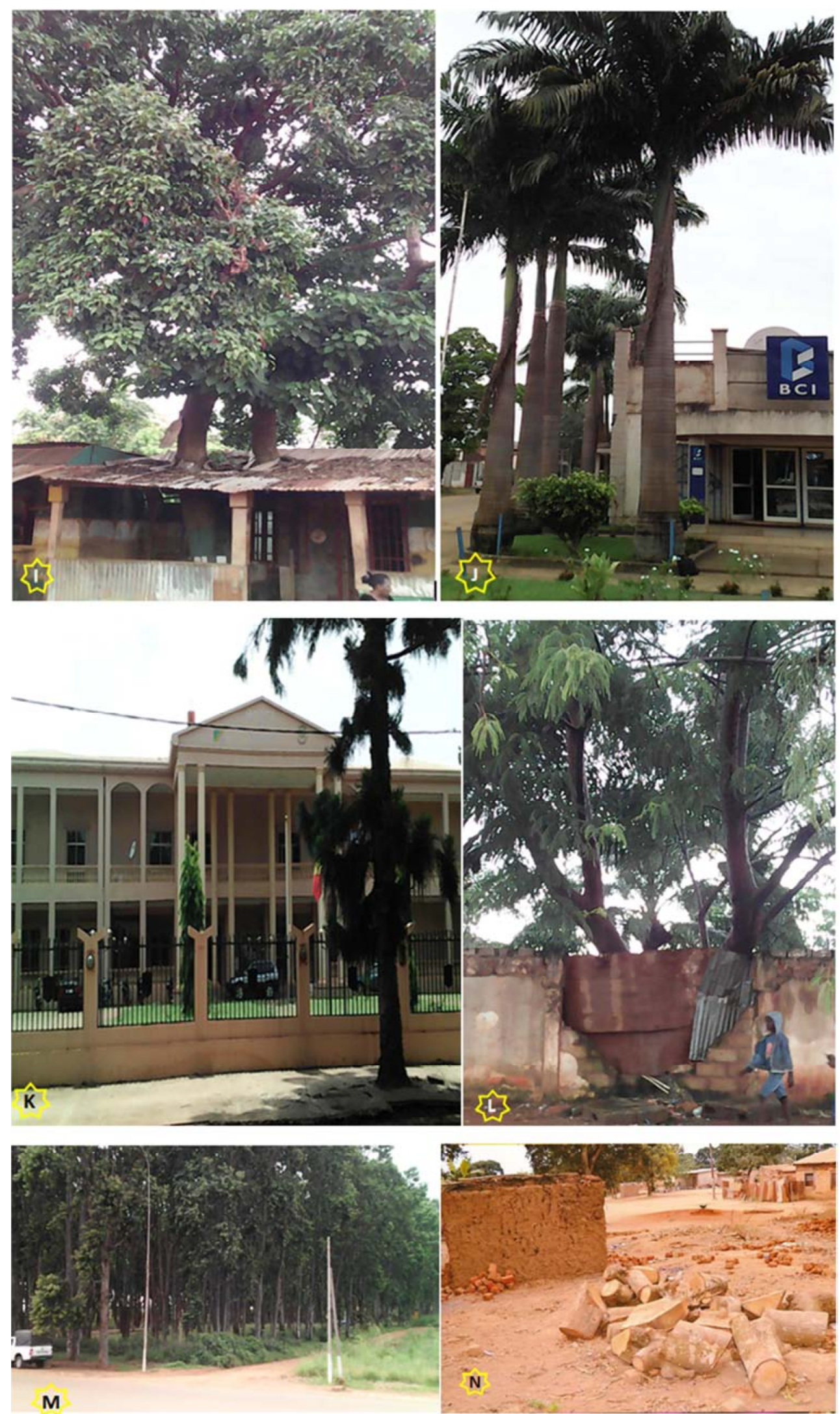

Figure A1. Synopsis of urban forestry in Dolisie

Legend: Mangifera indica (A) and Terminalia mantaly (B) street with trees; Delonix regia (C, G), Millettia laurentii (D), Ceiba pentandra (E) and Trilepisium madagascariense $(\mathrm{F})$; view of the public garden showing its new function $(\mathrm{H})$; shade and ornamental plants: Hura crepitans (I) in the popular district; Roystonea regia (J), Araucaria sp. and Polyalthia longifolia $(\mathrm{K})$ in the administrative district; damage caused by Delonix regia $(\mathrm{L})$ to the infrastructure in the administrative district; Eucalyptus platyphylla (M) in front of the Presidential Palace; remaining energy wood of Mangifera indica after firing the bricks (N). 


\section{References}

[1] FAO, "Urban and peri-urban forestry: Case studies on developing countries," Rome, 2001, 207 p.

[2] J. R. Miller, "Urban forestry: Planning and management of green space," Prentice Hall, pper Saddle River, New Jersey, 1997, pp. 22-67.

[3] FAO, "Synthesis of thematic studies on urban and peri-urban forestry in N'Djaména, Chad: Support for the formulation of an urban and peri-urban forestry strategy and action plan in N'Djaména," Republic of Chad. Discussion paper on urban and peri-urban forestry $n^{\circ} 7$, Rome, 2012, $114 \mathrm{p}$.

[4] E. J. Carter, "The future of urban forestry in developing countries: a discussion paper," Forest Department, FAO, Rome, 1995, 95 p.

[5] P. Botolisam, R. Raoufou, K. Kouami, Perceptions, trends and preferences in urban forestry: the case of the city of Lomé in Togo. European scientific Journal, 2014, pp. 261-277.

[6] F. Kumutima Agima, "Importance and nature of the tree in the city of Kinshasa: case of the commune of Ngaba," 2009, 20 p. Consulted on $16^{\text {th }}$ February 2017 in http:/ www mémoire online. com/04/11/4516/.

[7] D. Nzala, P. Miankodila, "Trees and green spaces in Brazzaville (Congo)," Tropical Woods and Forests, 272(2): 2002, pp. 88-92.

[8] V. Kimpouni, P. Mbou, E. Apani et M. Motom, "Floristic diversity and structural parameters of the Brazzaville Patte d'Oie forest, Congo" Open Journal of Ecology. 3(8): 2013a, pp. 518-531.

[9] V. Kimpouni, P. Mbou, G. Gakosso et M. Motom, "Flora biodiversity of the undergrowth and natural regeneration of the Patte d'Oie forest in Brazzaville, Congo", International Journal of Biological and Chemical Science. 7 (3): 2013b, pp. $1255-1270$.

[10] V. Kimpouni, E. Apani, P. Mbou et M. Motom, Floral study of the natural forest islets in the Patte d'Oie forest of Brazzaville, Congo. Acta Botanica Gallica. 16 (1): 2014, pp. 63-79.

[11] V. Kimpouni., M. Y. Lenga-Sacadura, R. S. Kalath \& L. Kiangana-Ngoyi, "Flora diversity of epiphytes and vascular hemiparasites in the urban forest ecosystem of Brazzaville, Congo," Journal of Applied Biosciences 117: 2017a, pp. 11704-11719. https://dx.doi.org/10.4314/jab.v117i1.7.

[12] V. Kimpouni, M.-Y. Lenga-Sacadura, R. C NkounkouLoufoukou and J. C. Mamboueni, "Survey of the Anthropic Actions and the Urban Woody Flora Exploitation in Brazzaville (Congo)," International Journal of Current Research and Academic Review. 5 (7): 2017b, pp. 38-51. DOI: https://doi.org/10.20546/ijcrar.2017.507.007.

[13] V. Kimpouni., S. D. Mbouba \& M. Motom, "Study of the non-native tree flora and urban forestry in Brazzaville (Congo)", Journal of Botany of the French Botanical Society 79: 2017c, pp. 73-92.

[14] A. Górniak, A. Alexandropoulou, B. Edlich, C. Smaniotto Costa, D. Horváth, H. Kasperidus, I. Šuklje-Erjavec, J.
Kozamernik, J. Mathey, K. Seidel, K. Bialas, K. Lalenis, M. Šinigoj, M. Richter, M. Bocci, N. Nikolova-Deme, P. Arvanitidis, S. Fuchs, T. Egedy, W. Reichel, "A Guide for Urban Green Quality," IOER Leibniz Institute of Ecological and Regional Development, Dresden. August 2008. Disponible sur: < www.greenkeys-project.net > (consulté le 09.01.2019). ISBN 978-3-933053-32-0

[15] P. Moundza P, "The daily life of urban arteries in Congo, L'Harmattan. African Studies Series", Paris, 2017, 116 p.

[16] J.-R., Pitte, "Atlas of Congo and Africa. Jaguar Editions" Paris, 2015, 255 p.

[17] G. Serpantié, P. Méral P. et C. Bidaud, "The benefits of nature to ecosystem services", VertigO- the electronic journal in environmental sciences, Volume 12 Num. 3, 2012, [online] URL: http://vertigo.revues.org/12924. DOI: $10.4000 /$ vertigo. 12924

[18] S. D. Dieng, M. Diop, A. Goudiaby, F. Niang-Diop, L. Codou Faye, I. Guiro, S. Sambou, A. M. Lykke and B. Sambou, "Characterization of ecosystem services provided by Cordyla pinnata in the periphery of the Patako Classified Forest in Senegal," VertigO - the e-journal in environmental sciences[Online], Volume 16(2), 2016.| September 2016, online since 09 September 2016, accessed on 06 December 2017. URL: http://vertigo.revues.org/17634; DOI: 10.4000/vertigo. 17634

[19] A. Diatta Amakobo, "Ecosystem services of the agroforestry park at Cordyla pinnata (Lepr. ex A. Rich.) Milne-Redh. in the southern Arachidier Basin (Senegal)," Int. J. Biol. Chem. Scs, 10 (6): 2016, pp. 2511-2525.

[20] MEFPPPI 2, "General Population and Habitat Census 2007 (RGPH 07)," Volume 2. State and structure of the population. Brazzaville. Saint-Paul Editions, 2012, 76 p.

[21] A. Aubréville, "Climates, Forests and Desertification of Tropical Africa". Geographical, maritime and colonial publishing companies, Paris, 1949, $315 \mathrm{p}$

[22] P. Vennetier, "Atlases of the People's Republic of Congo," Jeune Afrique Editions, Paris, 1977, 64 p.

[23] M.-J. Samba Kimbata, "The climate in the Congo," Doctoral thesis 3rd cycle Geography, University of Dijon, Dijon, 1978, $280 \mathrm{p}$.

[24] R. Jamet, J. M. Rieffel, "Information Folder No. 65. Soil map of Congo at 1/200,000. Sheet Pointe-Noire. Sheet Loubomo." ORSTOM, Paris, 1976, 167p.

[25] APG, "An update of the Angiosperm phylogeny group classification for the orders and families of flowering plants: APG IV," Botanical Journal of the Linnean Society, 181(1): 2016, pp. 1-20, DOI:10.1111/boj.12385

[26] J.-P. Lebrun and A. L. Stork, "Enumeration of flowering plants in tropical Africa and Tropical African Flowering Plants: Ecology and Distribution," vol. 1-10, 1991-2015. Published by the Conservatory and Botanical Garden of the City of Geneva, Geneva. Available at: http://www.villege.ch/musinfo/bd/cjb/africa/recherche.php?la ngue $=$ en

[27] F. Dallmeier, "Long-term monitoring of biological diversity in tropical forest areas, method of establishment and inventory of permanent plots," MAB, Digest 11, UNESCO, Paris, 1992, 112 p. 
[28] Millenium Ecosystem Assessment (MEA), "Ecosystems and human well-being: a framework for assessment," Island Press, Washington DC, 2003, 245 p.

[29] Millenium Ecosystem Assessment (MEA), "Ecosystems and Human Well-being: Synthesis," Island Press, Washington DC, $2005,140 \mathrm{p}$.

[30] M. E. Dossou, G. L. Houessou, O. T. Lougbégnon, A. H. B. Tenté and J. T. C. Codjia, "Ethnobotanical study of the wood forest resources of the Agonvè swamp forest and related soils in Benin," Tropicultura, 30(1): 2012, pp. 41-48.

[31] U. P. Albuquerque, R. F. P. Lucena, J. M. Monteiro, A. T. N. Florentino et C. F. C. B. R. Almeida., "Evaluating two quantitative ethnobotanical techniques," Ethnobotany Research \& Applications, 4: 2006, PP. 51-60.

[32] M. Heinrich, A. Ankli, B. Frei, C. Weimann et O. Sticher "Medicinal plants in Mexico : healers' consensus and cultural importance," Social Science \& Medicine 47: 1998, pp. 18591871. DOI: 10.1016/S0277-9536(98)00181-6

[33] A. Andrade-Cetto, et M. Heinrich, "From the field into the lab : useful approaches to selecting species based on local knowledge," Frontiers in Pharmacology, 2(20): 2011, pp. 1-5. DOI: 10.3389/fphar.2011.00020

[34] M. Z. Uddin et M. A. Hassan, "Determination of informant consensus factor of ethnomedicinal plants used in Kalenga forest, Bangladesh," Bangladesh Journal of Plant Taxonomy, 21(1): 2014, pp. 83-91. DOI: 10.3329/bjpt.v21i1.19272

[35] J. Friedman, Z. Yaniv et D. Palevitch, "A preliminary classification of the healing potential of medicinal plants, based on a rational analysis of an ethnopharmacological field survey among Bedouins in the Negez desert," Israel, Journal of Ethnopharmacology, 16: 1986, pp. 275-287. DOI: 10.1016/0378-8741(86)90094-2

[36] Certu, 2009. Characterization of public green spaces according to their place in the urban environment. CERTU/ADF Urban Planning Guide, $50 \mathrm{p}$.
[37] V. Le Houérou and J. le Houérou, "The traveller's tree plants gardens in tropical Africa," Paris, France, the new African editions. 1987, $186 \mathrm{p}$.

[38] P. Laille, D. Provendier and F. Colson, "The benefits of plants in the city: Synthesis of scientific work and method of analysis". Plant \& City, 2013, 36 p.

[39] H. F. Kaya, "Contribution to the study of urban forestry in the city of Dolisie". Master's thesis of Professor of Secondary Education Natural Sciences, Marien Ngouabi University. 2017, 74 p.

[40] L. Nsiloulou, "Trees in the City of Brazzaville," Theses of Master's Degree, Department of Geography, FLSH, UMNG, Brazzaville, 2002, 110 p.

[41] R. Ulrich, "View through a window may influence recovery from surgery," Science, vol. 224, n 4647, 1984, pp. 420-421.

[42] C. Mbow, "Potential and Dynamics of Carbon Stocks in Sudanese and Sudano-Guinean Savannah in Senegal," $P h D$ Thesis, Cheikh Anta Diop University, Dakar, Senegal, 2009, $319 \mathrm{p}$.

[43] C. Mbow, M. M. Verstracte, B. Sambou, A. T. Diaw, H. Neufeldt, "Allometric maize in the Sudanese zone of Benin," Int. J. Biol. Chem. Sci. 6 (5): 2014 pp. 2066-2082.

[44] C. Legenne. "Without greenery, the city suffocates. The note of the Institute of Planning and Development on the vulnerability of the city to heat," 2015, 4 p.

[45] P. Ozenda, "Plants in the Biosphere," Doin, Paris, 1982, 432 p.

[46] M. Raffard, "Allergy to tropical plants". Pasteur Institute, Alger, 2009, 55 p.

[47] A. Helbling, "Allergy to pollen. aha! Swiss Allergy Centre," $2010,12 \mathrm{p}$.

[48] I. Demers, "State of knowledge on pollen and allergies: the foundations for effective management," National Institute of Public Health of Quebec. 2013, 111 p. 